\title{
Determinants of Cost Differences Between Indonesian- Case Based Groups Tariff and Hospital Tariff for Stroke Patients: A Path Analysis Evidence from UNS Teaching Hospital Sukoharjo, Central Java
}

\author{
Dewi Wulandari ${ }^{1,2)}$, Dono Indarto3), Didik Tamtomo4) \\ 1)Masters Program in Public Health, Universitas Sebelas Maret \\ ${ }^{2}$ General Practitioner, UNS Teaching Hospital, Sukoharjo \\ 3)Department of Physiology, Faculty of Medicine, Universitas Sebelas Maret \\ 4)Department of Anatomy, Faculty of Medicine, Universitas Sebelas Maret
}

\begin{abstract}
Background: In the scheme of National Health Insurance System, hospital must adapt to the newer financial system by regularly doing quality and cost assurance. Stroke, a catasthrophic disease, has a high financial impact on hospital cost. This study aimed to examine the determinants of cost differences between Indonesian Case Based Groups (INA-CBGs) dan hospital tariff for stroke patients in UNS Teaching Hospital, Sukoharjo.

Subjects and Method: An analytic observation was perfomed in this study from April to May 2019 by with used the cross sectional design. Recruitment of 113 stroke patients was determined using a fixed disease sampling. The dependent variable was cost difference. The independent variables were length of stay, intensive care use, medicine tariff, severity level, and type of class treatment. The data were obtained from hospital medical record and analyzed by path analysis.

Results: Medicine tariff was the strongest factor that influenced the difference of tariff $(\mathrm{r}=-0.65$; $\mathrm{p}<0.001)$. Medicine tariff $(\mathrm{b}=-3.57 ; 95 \% \mathrm{CI}=-4.34$ to $-2.80 ; \mathrm{p}<0.001)$ and type of class treatment $(b=1508.70 ; 95 \% \mathrm{CI}=247.54$ to $2769.87 ; \mathrm{p}=0.019$ ) were directly influenced the difference of tariff. Length of stay $(b=122.18 ; 95 \% \mathrm{CI}=89.52$ to $154.84 ; \mathrm{p}<0.001)$, intensive care use $(b=1161.50 ; 95 \%$ $\mathrm{CI}=844.01$ to $1478.99 ; \mathrm{p}<0.001)$, severity level $(\mathrm{b}=375.58 ; 95 \% \mathrm{CI}=143.27$ to $607.90 ; \mathrm{p}=0.002)$ positively influenced the difference of tariff through medicine tariff. Severity level also influenced medicine tariff $(b=375.58)$, length of stay $(b=1.55)$, and intensive care use $(b=0.16)$.

Conclusion: The UNS Hospital cost for stroke patients exceeds the INA-CBGs tariff, which is influenced by medicine tariff and intensive care use.
\end{abstract}

Keywords: INA-CBG’s tariff, hospital tariff, stroke, UNS teaching hospital.

\section{Correspondence:}

Dewi Wulandari. Masters Program in Public Health, Universitas Sebelas Maret, Jl. Ir. Sutami 36A, Surakarta, Central Java, Indonesia. Email: dewulano023@gmail.com. Mobile: 085335705757

\begin{abstract}
RESULTS
Every year, 150 million people encounter a financial problem because they have to pay theirhealth care, which is not covered by any health insurance ( $\mathrm{Xu}$ et al., 2007). In Indonesia, health care payment from outof-pocket reached 45.3\% in 2012 (Trisnantoro et al., 2014). Therefore, this problem can lead to limitation of health access services. Based on the third program of Sus-
\end{abstract}

tainable Development Goals (SDGs), everyone has the same right to accesshealth care through Universal Health Coverage (UHC).

Indonesia has implemented the UHC by establishment of a National Health Insurance System (NHIS) or Jaminan Kesehatan Nasional (JKN), which was launched on January 1, 2014. For financial claims, the Sosial Security Agency for Health (SSAH) or Badan Penyelenggara Jaminan Sosial 
(BPJS) handles this system. Before the NHIS era, some health insurance such as ASKES for government employeesprovide health care, and they have to pay financial claims by fee for services.

On the other hand, in this NHIS era the financial claims are paid by prospective payment (Indonesia Case-Based Groups, INA-CBGs). Consequently, every Indonesian hospital should have quality and cost assurance to address to the newer payment method. Catasthropic diseases like heart diseases and stroke have high financial impacts to hospital. Especially, stroke has become attention because the hospital cost often exceeds the INA-CBGs (Hadning et al., 2015; Muslimah et al., 2017; Feladita et al., 2014). Evers (2002) states that patients with stroke require more hospital resources, due to high levels of morbidity and mortality, prolonged treatment, intensive care use, and long-term healing conditions, compared to other patients without stroke. This study therefore aimed to analyze factors that influenced the differences between hospital tariff and INA-CBGs tariff for stroke patients in UNS teaching hospital.

\section{SUBJECTS AND METHOD \\ 1. Study Design \\ This analytic study with cross sectional design was conducted in UNS Teaching Hospital, Sukoharjo, from April to May 2019.}

\section{Population and Samples}

This research study involved 113 stroke patients. Those patients were selected using the fixed disease sampling and met criteria: had national insurance (BPJS), admitted in UNS Teaching Hospital between Januari and November 2018, and had first attack of stroke. They excluded from this study if reffered to other hospitals, were refferal from other hospitals, and did not continue the stroke treatment.

\section{Study Variables}

Independent variables were intensive care use, length of stay, medicine tariff, severity disease level, and medical ward class, whereas the dependent variable was the difference between INA-CBGs and hospital tariff. All data were collected using medical record and billing of selected patients.

\section{Study Variables}

Independent variables were intensive care use, length of stay, drugs tariff, severity disease level, and medical wardclass, whereas the dependent variable was the difference between INA-CBGs and hospital tariff.All data were collected using medical record and billing of selected patients.

\section{Data Analysis}

Univariate and multivariate analysiswere used to analyze all collected data. For univariate analysis, data were presented as number, percentage, and mean. The path analysis was run on Stata 13 to examine direct and indirect relationships between independentand dependent variables.

\section{Research Ethics}

The protocol of this study has been approved by The Ethical Committee of Medical Research, Faculty of Medicine, Universitas Sebelas Maret Surakarta.

\begin{tabular}{l}
\hline RESULTS \\
1. Sample Characteristics \\
As can be seen from Table 1, the gender \\
proportion of study subjects was similar \\
between female and male. The majority \\
among study subjects aged 46-65 years old \\
and had ischemic stroke. Around 60\% \\
study subjects used the non-Government \\
NHIS. After becoming in ward patients, the \\
average of medicine tariff was almost one \\
million and the length of stay of stroke \\
patients ranged from 1 to 16 days. There- \\
fore, the UNS hospital had to subsidize \\
hospital cost around IDR 1,949,440 for \\
every stroke patient.
\end{tabular}


Journal of Health Policy and Management (2019), 4(3): 176-181

https://doi.org/10.26911/thejhpm.2019.04.03.05

From Table 1, a half of stroke patients occupied class 3 that was the cheapest room. Mild stroke was found in $67.26 \%$

patients who were admitted in to the UNSHospital so that they did not need intensive care use.

Table 1. sample Characteristicsof

\begin{tabular}{|c|c|c|c|c|}
\hline Characteristics & $\mathbf{n}$ & $\%$ & Mean \pm SD & Min - Max \\
\hline \multicolumn{5}{|l|}{ Gender } \\
\hline Male & 56 & 49.56 & & \\
\hline Female & 57 & 50.44 & & \\
\hline \multicolumn{5}{|l|}{ Age } \\
\hline 26-45 years & 11 & 9.65 & & \\
\hline 46-65 years & 56 & 49.12 & & \\
\hline$>65$ years & 47 & 41.23 & & \\
\hline \multicolumn{5}{|l|}{ Type of Stroke } \\
\hline Ischemic & 88 & 77.88 & & \\
\hline Hemorrhage & 23 & 20.35 & & \\
\hline Unspecified & 2 & 1.77 & & \\
\hline \multicolumn{5}{|l|}{ Type of NHIS } \\
\hline Government & 44 & 38.94 & & \\
\hline Non-Government & 69 & 61.06 & & \\
\hline $\begin{array}{l}\text { Difference of tariff ( } x \text { IDR } \\
\text { 1,00o) }\end{array}$ & & & $\begin{array}{l}-1949.44 \pm \\
4484.96\end{array}$ & $\begin{array}{l}22806.50- \\
7287.29\end{array}$ \\
\hline Length of stay (day) & & & $7.09 \pm 3.28$ & $1-16$ \\
\hline Medicine tariff (x IDR 1,ooo) & & & $716.90 \pm 831.83$ & $76.61-4803.72$ \\
\hline \multicolumn{5}{|l|}{ Type of Class } \\
\hline Class 1 & 31 & 27.43 & & \\
\hline Class 2 & 25 & 22.12 & & \\
\hline Class 3 & 57 & 50.44 & & \\
\hline \multicolumn{5}{|l|}{ Level of severity } \\
\hline Mild & 76 & 67.26 & & \\
\hline Moderate & 20 & 17.70 & & \\
\hline Severe & 17 & 15.04 & & \\
\hline \multicolumn{5}{|l|}{ Intensive Care Use } \\
\hline Yes & 15 & 13.27 & & \\
\hline No & 98 & 86.73 & & \\
\hline
\end{tabular}

\section{Bivariate Analysis}

Results of the Pearson correlation test were presented in Table 3. There were different

Table 2. The results of bivariate analysis

\begin{tabular}{lcc}
\hline Independent Variables & $\mathbf{r}$ & $\mathbf{p}$ \\
\hline Medicine Tariff & -0.70 & $<0.001$ \\
Length of Stay & -0.65 & $<0.001$ \\
Type of Class & 0.13 & 0.1443 \\
Intensive Care Use & -0.43 & $<0.001$ \\
Severity Level & -0.15 & 0.0926 \\
\hline
\end{tabular}

Strong and negative relationships were observed in medicine tariff $(\mathrm{r}=-0.70)$ and length of stay ( $r=-0.65)$ to the difference of tariff and they reached significantly with $\mathrm{p}<0.001$. relationships among independent variables with difference of tariff. 
tariff and it was not statistically significant ( $\mathrm{p}=0.14$ and $\mathrm{p}=0.09$ respectively).

\section{Path Analysis}

Path analysis model in this study was depicted in Figure 1. Medicine tariff directly influenced difference of tariff and was affected by intensive care use and length of stay. Severity level and type of class became exogenous variables for difference of tariff.
The result of path analysis was then described in Table 3. Medicine tariff $(b=-$ 3.57; $95 \% \mathrm{CI}=-4.34$ to $-2.80 ; \mathrm{p}<0.001)$ and type of class $(b=1508.70 ; 95 \% \mathrm{CI}=247.54$ to $2769.87 ; \mathrm{p}=0.019$ ) directly and negatively influenced the difference of tariff. However, medicine tariff $(\beta=-0.65)$ had stronger influence than type of class $(\beta=0.47)$ in terms of the difference of tariff.

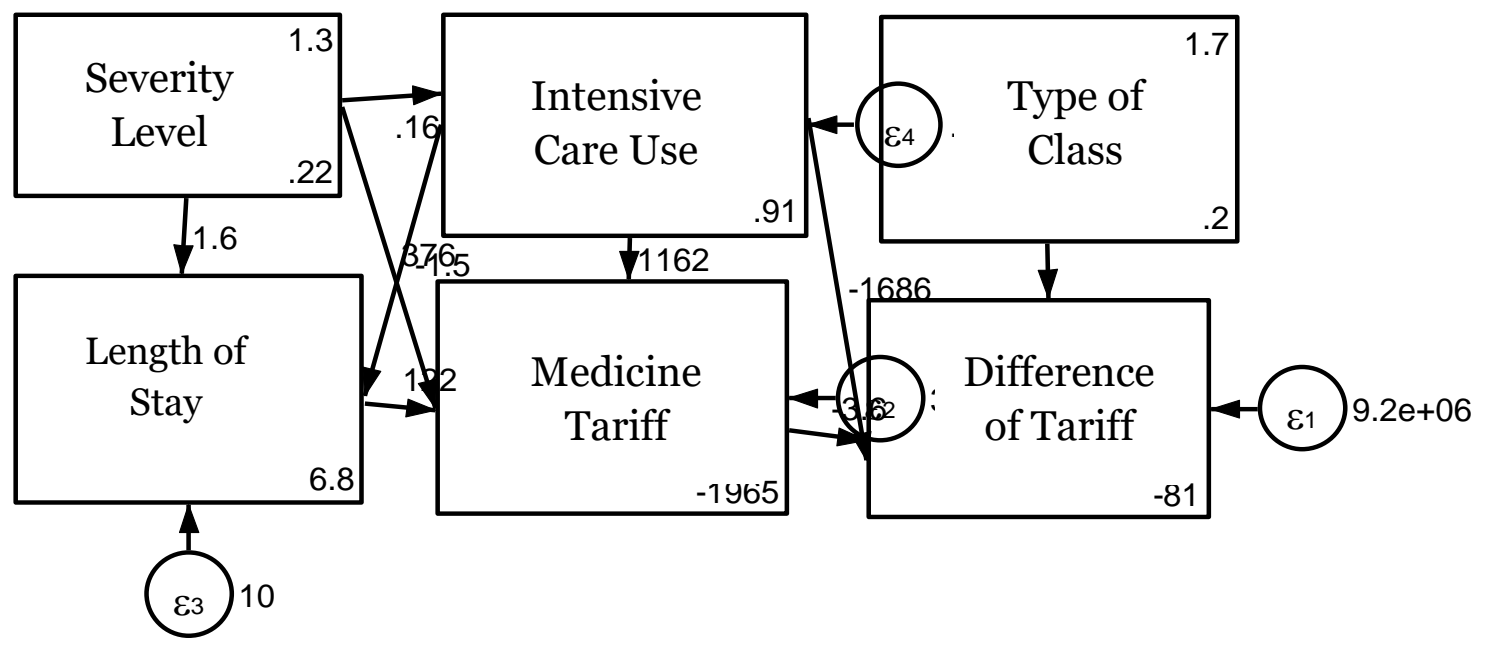

Figure 1. A Structural Model of Independent Variables and the Dependent Variable

Table 3. The results of path analysis

\begin{tabular}{|c|c|c|c|c|c|c|c|}
\hline \multirow{2}{*}{$\begin{array}{c}\text { Dependent } \\
\text { Variable }\end{array}$} & & \multirow{2}{*}{$\begin{array}{c}\text { Independent } \\
\text { Variable }\end{array}$} & \multirow[b]{2}{*}{ b } & \multirow[b]{2}{*}{$\boldsymbol{\beta}$} & \multicolumn{2}{|c|}{ (95\%) CI } & \multirow[b]{2}{*}{$\mathbf{p}$} \\
\hline & & & & & $\begin{array}{c}\text { Lower } \\
\text { Limit }\end{array}$ & $\begin{array}{c}\text { Upper } \\
\text { Limit }\end{array}$ & \\
\hline \multicolumn{8}{|l|}{ Direct Effect } \\
\hline \multirow[t]{3}{*}{ Difference of Tariff } & $\leftarrow$ & Medicine Tariff & -3.57 & -0.65 & $-4 \cdot 34$ & -2.80 & $<0.001$ \\
\hline & $\leftarrow$ & $\begin{array}{l}\text { Intensive Care } \\
\text { Use }\end{array}$ & -1685.53 & -0.12 & -3558.57 & 187.51 & 0.078 \\
\hline & $\leftarrow$ & Type of Class & 1508.70 & 0.47 & $247 \cdot 54$ & 2769.87 & 0.019 \\
\hline \multicolumn{8}{|l|}{ Indirect Effect } \\
\hline \multirow[t]{3}{*}{ MedicineTariff } & $\leftarrow$ & Length of Stay & 122.18 & 0.48 & 89.52 & 154.84 & $<0.001$ \\
\hline & $\leftarrow$ & $\begin{array}{l}\text { Intensive Care } \\
\text { Use }\end{array}$ & 1161.50 & 0.47 & 844.01 & 1478.99 & $<0.001$ \\
\hline & $\leftarrow$ & Severity Level & 375.58 & 0.21 & 143.27 & 607.90 & 0.002 \\
\hline \multirow[t]{2}{*}{ Length of Stay } & $\leftarrow$ & $\begin{array}{l}\text { Intensive Care } \\
\text { Use }\end{array}$ & -1.52 & -0.15 & -3.29 & 0.24 & 0.092 \\
\hline & $\leftarrow$ & Severity Level & 1.55 & -0.22 & 0.27 & 2.83 & 0.017 \\
\hline \multicolumn{8}{|l|}{ n Observasi= 113} \\
\hline $\begin{array}{l}\text { Log Likelihood }=-24 \\
\mathrm{~b}^{*}=\text { unstandardized } \\
\beta^{* *}=\text { standardized }\end{array}$ & $\begin{array}{l}1.22 \\
\text { path } \\
\text { ath c }\end{array}$ & $\begin{array}{l}\text { coefficient } \\
\text { oefficient }\end{array}$ & & & & & \\
\hline
\end{tabular}


In addition, intensive care use directly influenced the difference of tariff but it was not statistically significant $(\mathrm{p}=0.078)$. Length of stay $(b=122.18 ; 95 \% \mathrm{CI}=89.52$ to $154.84 ; \mathrm{p}<0.001)$, intensive care use $(\mathrm{b}=$ $1161.50 ; 95 \%$ CI $=844.01$ to 1478.99 ; $\mathrm{p}<0.001)$, severity level $(\mathrm{b}=375.58 ; 95 \%$ $\mathrm{CI}=143.27$ to $607.90 ; \mathrm{p}=0.002)$ influenced the difference of tariff through medicine tariff. Severity level influenced length of stay $(\mathrm{b}=1.55 ; 95 \% \mathrm{CI}=0.27$ to $2.83 ; \mathrm{p}=$ 0.017) and intensive care use $(\mathrm{b}=0.16 ; 95 \%$ $\mathrm{CI}=0.03$ to $0.29 ; \mathrm{p}=0.013$ ), that finally contributed to the medicine tariff.

\section{DISCUSSION}

In this present study, we have documented that medicine tariff is a stronger factor that directly influences to the difference of tariff in stroke patients, compared to type of class. Length of stay, intensive care unit, and severity level are other important factors that contribute to the medicine tariff. Meanwhile, severity level increases length of stay and intensive care use in stroke patients.

Our finding indicates that increase of IDR 1,000 medicine tariff will increase IDR 3,570 hospital loss for one stroke patient in the UNS Teaching Hospital. However, medicine tariff just has 10\% contribution to total hospital cost. Other factors that have higher contribution to the difference of tariff are nursing care, medical rehabilitation, length of stay, and laboratory and radiology examinations (unshown data). This study was in line with a study by Buisman et al., (2015) and Tuet al., (2003). They state that nursingcare is the highest factor affecting hospital cost.

Patients with stroke who occupy class 3 , the UNS Hospital has profit IDR $1,508,700$. By subtracting with medicine tariff, the Hospital still has profit from stroke patients. However, any patient who used the intensive care use, the UNS Hospital got loss IDR 1,685,530. From this case, the UNS Hospital consequently has deficit around IDR 180,000. Based on the result of path analysis, the intensive care use is not significant to influence the difference of tariff because only $13.27 \%$ patients with stroke used facilities of intensive care room.

The finance loss of UNS Hospital due to taking care of stroke patients is in accordance to previous studies conducted by Hadning et al., (2015); Muslimah et al., (2017); and Feladita et al., (2014). They found that hospital cost for stroke patients was higher than INA-CBGs tariff. Moreover, medicine costs from prescribed drugs and medical equipment uses are the highest proportion contributing to hospital cost for stroke patients (Hadning et al., 2015). In contrast to the earlier study, nursing care including room and length of stay utility is the highest cost for stroke patients (Muslimah et al., 2017; Feladita et al., 2014).

Another finding in this present study is that severity level of stroke directly affects intensive care use. It is not surprised that severe condition of patients with stroke definitely require more intensive care and use medical equipments (Nordin et al., 2012). For example, the UNS Hospital will spend much more money to take care stroke patients because they get further treatment of their underlying diseases such as hypertension and diabetes mellitus.

In conclusion, overall the UNS Hospital provides extra money to cover the difference of tariff with INA-CBGs tariff, which is directly influenced by medicine tariff and type of class. To minimize finance deficit from stroke patients, drugs uses should follow the national standard for stroke treatment. 


\section{AUTHOR CONTRIBUTIONS}

Dewi Wulandari collected the articles, examined meta-analysis, and wrote the manuscript. Dono Indarto examined meta analysis and interpreted the results of meta analysis. Didik Tamtomo gave suggestion of materials to discuss in this study about INA-CBGs tariff and hospital tariff.

\section{CONFLICT OF INTEREST}

We declare that there is no conflict of interest.

\section{FUNDING AND SPONSORSHIP}

There is no external fund.

\section{REFERENCE}

Buisman LR, Tan SS, Nederkoorn PJ, Koudstaal PJ, Redekop WK (2015). Hospital costs of ischemic stroke and TIA in the Neteherlands. American Academy of Neurology.

Evers S, Voss G, Nieman F, Ament A, Groot T, Lodder J, Blaauw G (2002). Predicting the cost of hospital stay for stroke patients: The use of diagnosis related groups. Health Policy (Amsterdam, Netherlands), 61(1): 21-42.
Feladita N, Satibi M (2014). Analisis Biaya Terapi Stroke Hemoragi Pada Pasien Rawat Inap. Jurnal Manajemen dan Pelayanan Farmasi.

Hadning I, Ikawati Z, Andayani TM (2015). Stroke Treatment Cost Analysis for Consideration on Health Cost Determination Using INA-CBGs. International Journal of Public Health Science (IJPHS). 4(4): 288-293.

Nordin NAM, Junid SAS, Aziz NA, Nur AM, Sulong S (2012). Direct Medical Cost of Stroke: Findings from a Tertiary Hospital in Malaysia. Med J Malaysia.

Trisnantoro L, Marthias T, Harbianto D (2014). Universal Health Coverage Assessment Indonesia. 1-16.

Tu F, Anan M, Kiyohara Y, Okada Y, Nobutomo K (2003). Analysis of hospital charges for ischemic stroke in Fukuoka, Japan. Health Policy. 66: 239246.

XuK, Evans DB, CarrinG, Aguilar-rivera A M, MusgroveP, Evans T (2007). Protecting households from catastrophic health spending. https://doi.org/10.1377/hlthaff.26.4.972. 